тывающем все виды человеческой жизнедеятельности, формирующем, по выражению Э.А. Орловой, ее «панкультурную специфику» [9, с. 4]. Таким образом, идеи русского символизма конца XIX - начала XX в. фактически демонстрируют правомерность суждений П. Сорокина о нарастании потребности в формировании идеалистического типа культуры, способного преодолеть кризисные тенденции, что подтверждается содержанием теоретических манифестов символистов, функция которых была связана с указанием направлений развития искусства, способного выразить актуальные смыслы современности, и с определением ценностных ориентиров в понимании не только искусства, но и культуры в целом.

\section{Список источников}

1. Астахов 0.Ю. Творческая деятельность в гносеологии символизма Андрея Белого (по материалам статьи «Эмблематика смысла. Предпосылки к теории символизма») // Вестник Челябинской государственной академии культуры и искусств. - 2015. - № 1 (41). - С. 55-61.

2. Бальмонт К.Д. Избранное: Стихотворения. Переводы. Статьи / К.Д. Бальмонт. - М. : Правда, 1991. - 608 с.
3. Бальмонт К.Д. Элементарные слова о символической поэзии // Литературные манифесты: От символизма до «0ктября». - М. : Аграф, 2001. - С. 52-61.

4. Бельчевичен С.П. Угроза дегуманизации культуры и религия в философии Д.С. Мережковского // Обсерватория культуры. - 2012. - № 3. - С. 120-124.

5. Брюсов В.Я. Сочинения : в 2 т. / В.Я. Брюсов. - М. : Художественная литература, 1987. - Т. 2. - 575 с.

6. Брюсов В.Я. Среди стихов: 1894-1924: Манифесты, статьи, рецензии / В.Я. Брюсов. - М. : Советский писатель, 1990. - 720 c.

7. Мережковский Д.С. Вечные спутники. Портреты из всемирной литературы / Д.С. Мережковский. - СПб. : Наука, 2007. - 907 c.

8. Мини 3.Г. 0 некоторых «неомифологических» текстах в творчестве русских символистов // Блок и русский символизм: Избранные труды : в 3 кн. - СПб. : Искусство, 2004. - Кн. 3 : Поэтика русского символизма. C. 59-96.

9. Орлова Э.А. Модерн как культурный стиль // Обсерватория культуры. - 2013. - № 4. - С. 4-23.

10. Ортега-И-Гассет Х. Избранные труды // Х. Ортега-иГассет. - М. : Весь мир, 1997. - 704 с.

11. Сорокин П. Человек. Цивилизация. Общество / П. Сорокин. - М. : Политиздат, 1992. - 543 с.

\title{
АНИСИМОВА Е.A.
}

\section{КАЗИМИР МАЛЕВИЧ: ФРАКТАЛИЗАЦИЯ КАК ПУТЬ К СУПРЕМАТИЗМУ}

В статье в свете теории фракталов обсуждаются художественные методы К. Малевича. Основные творческие идеи художника могут быть описаны с помощью представлений о визуальных, семиотических и динамических фракталах. Показано, что фрактальный анализ дает возможность обозначить живописные произведения К. Малевича как визуальные, семиотические и динамические фракталы, а фрактализация изображения позволяет достичь особых эффектов восприятия. Исследуется фрактальность «Черного квадрата». Рассматривается многомерная фрактальность архитектонов.

Ключевые слова: К. Малевич, визуальные фракталы, семиотические фракталы, динамические фракталы, «Черный квадрат», архитектоны.

K азимир Малевич - гениальный художник и признанный лидер мирового авангарда, великий теоретик искусства, создавший собственные художественные методы и всецело осознающий воздействие на зрителя определенных художественных приемов. В теоретизации своих творческих изысканий он предвосхитил многие будущие научные открытия и философские идеи, стал предвестником оригинальных творческих стратегий, о которых только сейчас заговорили теоретики искусства. В первую очередь, речь идет о предвосхищении, о предчувствии идеи фрактальности, ставшей общенаучной парадигмой в конце XX века.

Идея фрактальности, введенная в современную науку Б. Мандельбротом, стала той революционной идеей, которая позволила описывать чрезвычайно сложные пространственные объекты, мы не будем подробно 
останавливаться здесь на описании сложной структуры математических и физических фракталов, это многократно и подробно сделано [12; 16-19; 22; 24; 25; 27]. Скажем лишь, что под фракталом понимают множество, обладающее дробной размерностью и свойством самоподобия [6; 27]. В философской интерпретации фрактальность есть предельная сложность геометрической формы: единство прерывного и дискретного, целого и множественного; целостность дробящегося; дробность, мозаичность, калейдоскопичность частей изображаемого; подобие частей изображаемого и целого [7; 8]; сложность, не описываемая классической геометрией, но постоянно являемая природой (достаточно представить деревья или или звездное небо) и широко тиражируемая в культурных объектах (сети дорог, лабиринты городов, готическая архитектура, живопись импрессионизма). Дробная размерность означает, что фрактал не обладает свойствами непрерывности и гладкости, «не целиком заполняет» то пространство, в котором помещается: он дырчатый, сетчатый, «кружевной», изломанный, извилистый, запутанный, дробящийся, пористый, шероховатый, игольчатый, пестрый, лоскутный и т. д.

Сегодня теория фракталов является одной из самых популярных и эвристичных научных стратегий и успешно применяется для анализа множества природных и социальных феноменов и процессов $[1 ; 3 ; 8 ; 18 ; 19 ; 24$; 25]. В настоящее время известно также, что фракталами являются музыкальные, поэтические, живописные, архитектурные произведения $[2 ; 4 ; 9 ; 11 ; 20]$. 0писание объекта как фрактального становится необходимым, когда сложность его пространственной структуры не поддается исследованию классическими геометрическими методами, но является принципиальной для понимания его сущности, способа существования или функционирования.

Ранее мы уже писали, что фрактальность изображений играла особую роль и в живописи П. Филонова, и в творчестве В. Кандинского, позволяя добиться максимально сильного восприятия художественного произведения, и обосновывали эвристичность теории фракталов для анализа их творчества [2]. Но поскольку идея фрактальности пока остается инновационной для искусствоведения, позволим себе остановиться еще раз на тех моментах, которые, с нашей точки зрения, делают ее применение полезным и даже необходимым при анализе многих произведений искусства.

Начнем с того, что практически все произведения живописи и графики являются пространственными фракталами: во-первых, фрактальны (и это сейчас хорошо известно!) изображаемые на них природные объекты (тела человека и животных, растения, ландшафты, звездное небо и пр.); во-вторых, сами художественные артефакты обладают значительной пространственной сложностью, геометрической нетривиальностью, для них характерны негладкость, прерывность, дискретность, сингулярность, изломанность, «угловатость», сетчатость, шероховатость - типичные характеристики фракталов. Вообще, всякое художественное изображение в принципе фрак- тализирует изображаемое, лишает его гладкости и непрерывности, даже если они изначально присутствуют. Этот факт легко проиллюстрировать: достаточно представить себе любую гладкую фигуру, которая на изображении дробится многочисленными мазками или графическими линиями. Произведения изобразительного искусства могут быть интерпретированы даже как «фракталы в квадрате», поскольку фрактальность изображаемого и фрактальность изображения усиливают друг друга. Но ведь именно пространственные характеристики произведения искусства и являются одним из самых важных предметов исследования искусствоведения, эстетики, культурологии. И описание фрактальных произведений на языке классической геометрии (гладкими линиями, классическими геометрическими фигурами) является существенным упрощением, которое «недодает» им сложности, в то время как теория фракталов располагает арсеналом понятий, методов и средств, способных справиться со всей пространственной сложностью фрактального артефакта.

Особо подчеркнем, что использование теории фракталов для анализа произведений искусства - это не дань научной «моде», не следование методологическому анархизму, не эпистемологическое излишество. Теория фракталов может и должна применяться в следующих случаях: когда классические геометрические представления прекращают работать, форма произведения становится слишком сложной, важные пространственные эффекты не описываются традиционными методами. Фрактальные стратегии исследования могут обогатить теорию искусства новыми интересными идеями и результатами, пополнить анналы искусствоведения, культурологии, философии культуры мощной, эвристичной и эффективной методологией, способной выявлять особенности композиции, принципы создания художественных произведений, обнаруживать глубины их семиотического содержания. Так, можно показать, что фрактальными принципами во многом руководствовалось искусство русского и европейского авангарда: кубизм предлагал всевозможные «разложения», которые можно трактовать как фрактальное дробление изображения; лучизм повторение частей, самоподобие; присущий авангарду симультанизм - совмещение нескольких точек зрения [2]. Часто встречающееся в абстрактном искусстве равноправие частей, отсутствие единого композиционного центра также согласуются с неизменным для всех фракталов свойством неравновесности - наличием нескольких устойчивых состояний [2].

Однако теория фракталов имеет не только теоретическое, но и прикладное значение, поскольку располагает значительным арсеналом методов количественного анализа, позволяющих точно определять некоторые важные характеристики произведений искусства. Например, уже сейчас при анализе музыкальных произведений широко применяется расчет фрактальных размерностей, которые, как оказалось, являются мерой воздействия на слушателя [9]. Существуют и гипотезы, согласно которым фрактальные размерности являются уникальными маркерами 
авторского «почерка» живописцев, и это дает реальную возможность проводить квалифицированные экспертизы, идентифицировать художественные полотна, устанавливать авторство.

Есть и еще один, важнейший в контексте данного исследования, аспект теории фракталов, на котором нам следует остановиться отдельно. Речь идет о семиотических фракталах, которые исследует недавно возникшее направление семиотики - фрактальная семиотика. По определению В.В. Тарасенко, «семиотический фрактал - это перцептивно-лингвистическая (квази-лингвистическая) знаковая структура, при наблюдении которой наблюдатель, наблюдает новые знаки при изменении масштаба наблюдения» [21]. В этом определении подчеркивается существенное свойство фракталов: обнаруживать структурную иерархию при увеличении масштаба разрешения. Именно так семиотический фрактал при более внимательном осмыслении, смысловом «разглядывании» обнаруживает все новые и новые смыслы, скрытые от невнимательного наблюдателя, демонстрирует сложную смысловую иерархию. Подобные представления позволяют говорить об иерархии смыслов и отдельно взятого художественного произведения, о подобиях смыслов разных художественных произведений и «венках» смыслов. Нужно ли говорить о том, насколько важными оказываются эти представления в случаях анализа произведений искусства со множественными сложными смыслами, особенно тех, в которых эти смыслы сознательно «конструировались» авторами? И мы предполагаем, что многие произведения русского художественного авангарда являются именно такими семиотическими фракталами [2].

Цель настоящей работы - исследовать «фрактальные» художественные приемы и изобразительные средства, открытые К. Малевичем, показать, насколько значимыми они были для его искусства. Это позволит по-новому оценить авторские замыслы художника и принципы создания его произведений, более точно интерпретировать особенности построения его композиций, раскрыть семиотическую глубину его полотен как сознательно «сконструированных» на основе тех его представлений, которые в свете современного знания о мире с полным основанием могли бы называться фрактальными. Мы не собираемся просто устанавливать факт фрактальности произведений Малевича - в свете сказанного он может показаться даже тривиальным, а предполагаем исследовать те эффекты зрительского восприятия, которые достигались художником с помощью целенаправленной фрактализации изображаемого.

Начнем с того, что К. Малевич, по сути, описывает саму идею фрактальности как художественное новшество, значимое для восприятия. В своем очерке «0т Сезанна до супрематизма» художник так говорит о своем кубистическом подходе: «Идея состояла в том, чтобы не передавать целостность предметов; напротив, было крайне необходимо распылить объект, подвергнуть его декомпозиции на составляющие элементы, с тем чтобы создать живописные контрасты» [15]. Но описанный Малевичем прием есть не что иное, как фрактализация изображения (разделение его на составные части, дробление), которая дает необходимый для художника эффект восприятия («живописные контрасты»). По Малевичу, такого эффекта невозможно достичь в гладком изображении, где «целостность предметов» сохранена.

Уже этого заявления достаточно, чтобы говорить о «фрактальных» идеях Малевича. Но он не просто призывает строить фрактальные композиции, а идет дальше: видоизменяет аналитический кубизм, в котором дробленые (фрактальные) изображения строятся по фрактальному принципу, «под себя»; усложняет и без того сложный метод, добавляя к очевидной геометрической дробности цветовую. В самом деле, Малевич делает свои, «распикасенные», изображения гораздо более цветными, чем это позволяет аналитический кубизм, в котором преобладают локальные цвета, а изображения практически всегда выглядят монохромными. Многообразие ярких оттенков в работах Малевича усиливает эффект «взрыва» плоскостей, создает ощущение, что грани радужно переливаются всеми цветами, светятся. Максимально «раскрашивая» изображение, художник превращает чисто геометрические фракталы в геометрическо-цветовые, что еще более усиливает визуальную фрактальность. Подобная суперпозиция «фрактальных приемов» позволяет Малевичу увеличить сложность и дробность изображения и, выражаясь языком современной теории фракталов, повысить фрактальную размерность (степень фрактализации) изображаемого, а как результат - усилить зрительские эффекты.

Остановимся на том, какой эффект возникает при подобной фрактальной «раскраске». В своих полотнах с крестьянками («Уборка ржи», «Утро после грозы», «Голова крестьянки») Малевич наряду с многообразием оттенков использует интереснейший цветовой прием, придающий дополнительный объем каждой грани и изображению в целом (то, что в современной компьютерной графике называется термином «деграде»). Он разбивает изображаемые объекты не на плоские грани, а на выпуклые и вогнутые поверхности. В результате возникает не только эффект «взрыва», когда изображаемое дробится на множество смещающихся друг относительно друга поверхностей, но и впечатление искривления пространства, что, возможно, уже являлось отголоском будущей философии Малевича. Заметим, что в современной топологии подобные сложные, искривленные, динамически меняющие свою структуру пространства называются топосами и предполагают особые эффекты восприятия [5].

Однако Малевич не останавливается только на наложении геометрических и цветовых фракталов, а целенаправленно создает еще более радикальные художественные процедуры. Что касается самой геометрии изображения, то в отличие от мастеров аналитического кубизма он не только рассекает статическое изображаемое на грани, как это делает, например, Пикассо, но «движет» ими, сообщает им динамику, даже называет свои произведения «динамическими». Именно в этом 
движении и состоит важнейшее отличие кубофутуризма Малевича от традиционного кубизма: кубофутуризм как непосредственный преемник футуризма, для которого передача движения и скорости была важнейшей художественной задачей изобразительного искусства, невероятно подвижен и динамичен.

Для иллюстрации сказанного обратимся к картине «Динамическая декомпозиция крестьянки с ведрами» (1912 г. Холст, масло, 80,3 × 80,3 см, Нью-Йорк, Музей современного искусства), дающей наглядное представление о векторе его творческих поисков. Уже из названия картины ясно, насколько сознательно Малевич использует прием декомпозиции, как осмысленно он «препарирует» крестьянку и «движет» частями изображения. Здесь кисть художника с очевидностью объединяет кубизм и футуризм: фигура крестьянки рассечена на плоскости, а сами плоскости движутся подобно тому, как играют складки юбки при ходьбе. Пространство не только ломается, но и кривится, даже выворачивается. 0 чем-то подобном писал в работе «Мнимости в геометрии» П. Флоренский: «...и тогда наступают качественно новые условия существования пространства... Все пространство мы можем представить себе двойным, составленным из действительных и совпадающих с ним мнимых гауссовых координатных поверхностей, но переход от поверхности действительной к поверхности мнимой возможен только через разлом пространства и выворачивание тела через самого себя» [23, с. 61].

В этой картине Малевич использует и излюбленный футуристами прием, симультанизм (наличие одновременно нескольких точек зрения на картину). Так, дома в левом верхнем углу картины то ли даны в обратной перспективе, то ли попросту расположены сверху; с иных, отличных от прямого, ракурсов видятся и домики на заднем плане. Это тоже придает картине дополнительную динамику: кажется, что изображаемые объекты движутся, и взгляд не успевает за их поворотами, выхватывает то ту, то другую их часть под различными углами зрения. Но симультанизм свидетельствует и о принципиально ином зрении смотрящего: Малевич дарит зрителю способность охватывать взглядом изображаемый объект с разных сторон. Такова и концепция «Всевидящего ока» Малевича: благодаря магической кисти художника «всевидящим оком», способным смотреть во все стороны, начинает наделяться всякий зритель. Напомним, что ранее мы интерпретировали симультанизм как неравновесность и показали, что с его помощью удается показать разворачивание во времени некоторого процесса, стимулировать движение взгляда, позволить зрителю домысливать произведение [2]. Подобным же образом симультанизм используется и у Малевича, например, в картине «Лесоруб» (1912-1913 гг. Холст, масло, 94 × 71,5 см, Амстердам, Городской музей).

Совершенно иначе применяется симультанизм на полотне Малевича «Точильщик» (1912-1913 гг. Холст, масло, 79 × 79 см, Нью-Хейвен, Художественная галерея Йельского университета). Видно, что художник создает

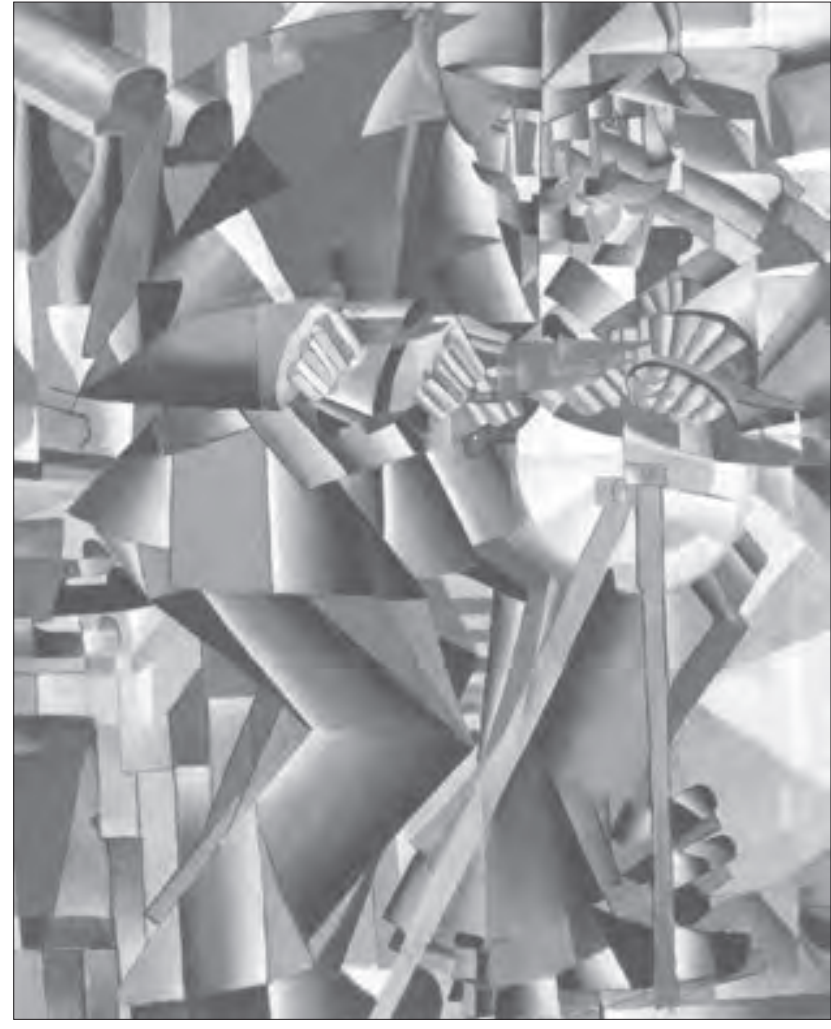

Симультанизм как фрактальный прием на картине К. Малевича «Точильщик». 1912-1913 гг. Холст, масло. 79 × 79 см. Нью-Хейвен, Художественная галерея Йельского университета

почти совершенный по форме концентрический фрактал, который образован фигурой точильщика, разбившейся при движении на грани, и кубической абстракцией фона. Здесь части фигуры: углы, грани, многократно «срезанные» профили, локти, колени, многочисленные носы и руки (и тех, и других насчитывается восемь), пальцы, колени, стопы - все повторено многократно и подчинено круговому движению заточки. Особое внимание обращают на себя пальцы: они не только повторяются всякий раз, когда повторяется кисть, но их число на каждой руке различается. Это уже не просто движение, это стремительная динамика, при взгляде на которую вспоминаются известные слова Бурлюка: «У вас две ноги, если Вы сидите и разглядываете свои ноги, но если Вы бежите, их двенадцать» [цит. по: 10, с. 60-61]. Однако эффект движения не был бы столь достоверным без следующего изобразительного приема: Малевич конструирует не просто концентрический, а «центробежный», взрывающийся фрактал - самоподобный, растущий от центра геометрический объект с большим числом плотных и мелких частей в «сердце фрактала», с более крупными частями на его внешних участках, что создает впечатление плотности, густоты, максимальной силы, напряжения в середине композиции, в месте совершения действия; концентрирует внимание именно на источнике - и в данном случае это подлинная, предельно зримая и специально созданная «кон-центрация». Именно продуманная фрактальность этого изображения и обусловливает ни с чем не срав- 


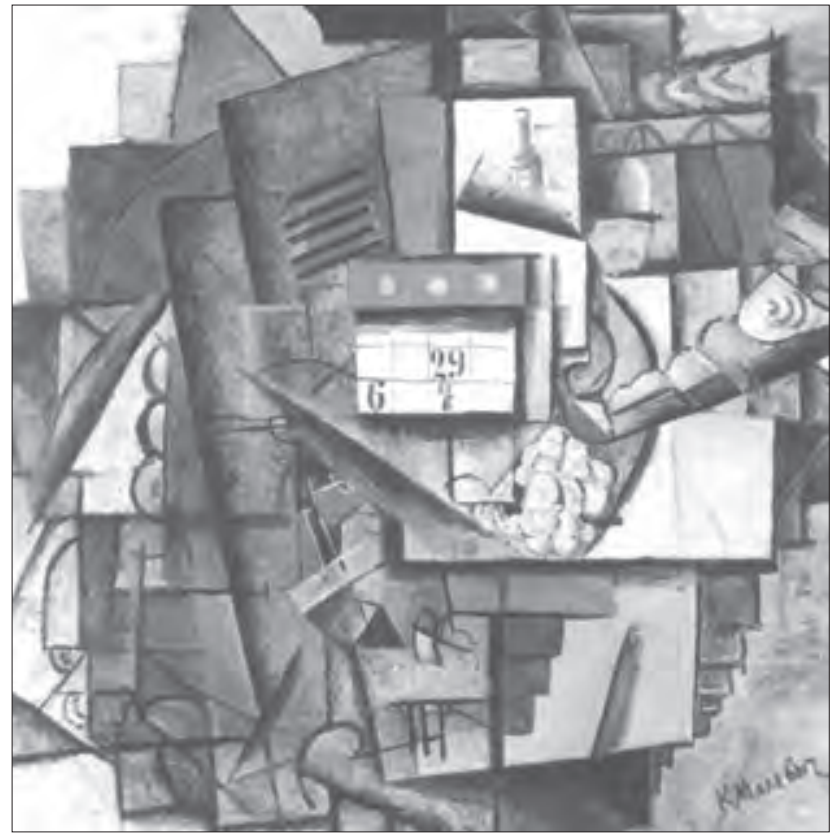

Алогизм как средство семиотической фрактализации на картине К. Малевича «Дама на остановке трамвая». 1913. Холст, масло. 88 × 88 см. Амстердам. Городской музей

нимый эффект многомерности и динамики. А у зрителя, помимо ощущения пространства, возникает и восприятие разворачивания действия во времени.

Итак, визуальную фрактальность, образованную геометрией и цветом, Малевич усиливает симультанизмом, движением частей, ростом их числа в определенном направлении (в описанном случае - к центру) и создает при этом многомерные растущие, динамические, визуально-временные фракталы. Вот что он пишет по этому поводу: «Предметы обладают множеством кратковременных моментов, их аспекты варьируются, и точно также живописное отражение их тоже делается разнообразным. Все эти временные аспекты предметов и их анатомии... охватывает интуиция, как средство конструирования полотна... Данные средства конструируются так, что неожиданный характер встречи двух анатомических структур создает диссонанс, в результате чего возникает сила воздействия чрезвычайного напряжения, оправдывающая появление частей реальных предметов там, где они отсутствуют в действительности. Таким образом, мы предпочли диссонанс предметов возможности отражения целостности самого предмета» [8]. Заметим, что сам Малевич особо подчеркивает, что целостное, или гладкое, изображение «силы воздействия чрезвычайного напряжения» не дает и потому является менее предпочтительным, в то время как «диссонанс», некий хаотический изъян создает удивительный эффект.

В этом месте следует особо остановиться на том, что фрактальность является важнейшей характеристикой всякого текста [4; 9]. В свете же современных философских представлений текстом является все, что содержит некоторый смысл, в том числе живописные и графические произведения. Необходимо отметить, что фрактальность удивительным образом обнаруживается как принцип, как кредо футуризма. Известно, насколько русский футуризм был богат на всяческие изобретения: это и сверхсложный, заумный, изобилующий неологизмами русский язык, и новые поэтические ритмы, и неслыханная странная музыка. Известно и то, каким сильным было влияние Малевича на участников этого движения, насколько сам он был пропитан футуризмом, вобрал все лучшее в футуризме, применяя его новейшие находки в своем искусстве. Знаменитый алогизм Малевича - это продолжение «зауми» В. Хлебникова и А. Крученых, и нет сомнений в том, что художник был верен принципу, декларированному А. Крученых в статье «Слово как таковое», вышедшей в журнале с обложкой К. Малевича в 1913 г.: «Чтобы писалось туго и читалось туго, неудобнее смазанных сапог или грузовика в гостиной (множество узлов, связок, петель и заплат, занозистая поверхность, сильно шероховатая» [13]. Используемые в этой фразе эпитеты и метафоры указывают, что созидаемый по этому принципу текст не может не быть фрактальным, ведь именно «узлы», «заплаты», «занозы», «шероховатости», «связки», «петли»это те самые сингулярности, особенности, которые собственно и составляют любой фрактал и принципиально отличают его от гладких множеств. В поэзии именно так писали В. Маяковский, Д. Бурлюк, Н. Бурлюк, Б. Лившиц, в живописи - Д. Бурлюк и К. Малевич.

Итак, сохраняя все свои прежние приемы, Малевич добавляет к ним взращенный на «заумной» футуристической почве алогизм. Вот, например, интереснейший пример алогичной работы «Дама на остановке трамвая» (1913 г. Холст, масло, 88 × 88 см, Амстердам, Городской музей). Здесь, кажется, есть все, уже апробированное Малевичем: фрактально-кубистическая абстракция, сложная цветность, динамичное смещение поверхностей, рекурсивное повторение частей. Есть и взорвавшийся на бесконечные грани стекол трамвай, от которого осталась лишь табличка с номером; есть и мужчина, держащийся всеми своими руками за множество поручней. Отсутствует только сама дама - она, пока зритель в ее поисках преодолевает все фрактально сконструированные художником препятствия, спокойно садится в трамвай и уезжает. Это алогизм, смысловая провокация, своеобразный неповторимый юмор Малевича.

Алогизм Малевича - это следующий шаг на пути максимизации фрактальности. До этого художник хаотизировал пространство: разлагал, расчленял и рассекал его, переворачивая и выворачивая, смешивая и путая части, - все это для того, чтобы зритель сам смог собрать из рассыпанных на холсте деталей «пазл», упорядочивая, детерминируя специально созданный хаос силой своего воображения. И это неслучайно: к хаотизации изображения тяготели практически все представители авангарда, и для понимания картин всегда требовалось активное участия зрителя. Возможно, именно поэтому авангард до сих пор так труден и неудобен (как «грузовик в гостиной»!) для восприятия большинства, ведь поиски смысла, 
воссоздание изначально разрушенного - непростые процедуры, которые по вкусу и под силу далеко не каждому. Но теперь Малевич придумывает нечто, куда более радикальное: отныне он хаотизирует не изображения, а смыслы! И если до этого он «взрывал» поверхности и краски, разворачивал детали, двигал, но все-таки изображал предметы, то теперь на его полотнах царят хаос и разруха: предметы разрушаются, их суть разлетается на осколки, взрываются, множатся и исчезают смыслы, умирает логика. И это решающий шаг на пути к провозглашенной Малевичем беспредметности.

До этого радикального шага, до хаотизации смысла работы Малевича можно было «решить» - сложить детали, склеить разбившееся. Теперь же зритель попадает в бесконечную ловушку: ведь разгадка всегда непредсказуема и не поддается «беззубой логике»', авторский смысл картины остается непостижимой тайной, а интерпретатору уготованы лишь тщетные попытки выиграть в игре без правил.

Теперь настало время вспомнить и хорошо известный современной науке факт: фрактал является графическим образом детерминированного (упорядоченного) хаоса, «следом» хаотической динамики [6; 7]. А хаос Малевича, несомненно, был упорядоченным, ведь, по его же собственным представлениям, скрытый, не поддающийся логике закон существует у любых алогически построенных композиций. Хаотизация смыслов логически завершает творческую «фрактальную стратегию» Малевича, его фрактально построенные композиции, фрактальную геометрию и фрактальную цветность. Хаотизация смыслов - это логический предел алогичного.

Хаотизируя смыслы, множа различные интерпретации, Малевич создает семиотические, или смысловые, фракталы, о которых мы говорили выше. Всякий семиотический фрактал при глубоком осмыслении обнаруживает все новые и новые смыслы, демонстрирует сложную смысловую иерархию, а любое изображение, изобилующее смыслами, по определению является семиотическим фракталом. Создавая семиотические фракталы, накладывая смысловую фрактальность на визуальную, геометрическую, цветовую, Малевич создает сложнейшие ментальные конструкции, так называемые комплексные фракталы [3], оказывающие на зрителя максимально сильное воздействие. Алогизм Малевича - закономерный итог его «фрактальной» творческой стратегии.

И даже в самую серьезную супрематическую пору Малевич не оставил привычку поиграть со зрителем, подзадорить его хаотизацией смыслов. Иначе зачем называть одно из величайших своих произведений - полотно «Красный квадрат» - «Крестьянкой в двух измерениях»? Другие супрематические композиции Малевича тоже носят алогичные названия: «Живописный реализм мальчика с ранцем», «Автопортрет в двух измерениях», «Живописный реализм футболиста», «Автомобиль и дама». Мале-

\footnotetext{
${ }^{1}$ Напомним, что Д. Бурлюк призывал разрушить «беззубую логику» в «Пощечине общественному вкусу».
}

вич, не жаловавший «целостные» изображения, не мог не понимать, что гладкие, упорядоченные, практически евклидовы, простые супремы не производят сами по себе достаточного впечатления. И целенаправленно усложнял супрематические полотна фрактальной семиотикой, усиливал их действенность парадоксальностью названий, провоцируя зрителя искать различные конкретные смыслы в бесконечном обилии смысловых составляющих.

Но в своих теоретических поисках Малевич не только опередил специалистов в области теории фракталов (причем более чем на полвека!), но и предвосхитил многие значимые философские идеи: и идеи феноменологии Э. Гуссерля (отказ от наперед заданных суждений и авторитетов, постоянный анализ, мысленное разбиение целостного на составляющие, целенаправленное смыслосозидание, воссоздание целого из деталей), и философскую деконструкцию Ж. Деррида (для которой устранение изначальных смыслов, разрушение общепринятых логических конструкций является принципиальным), и постмодернистскую идею «смерти автора» (предполагающую соучастие, смыслосозидающую активность читателя или зрителя в творении всякого произведения). А в своей иронии, алогизме, абсурдности, Малевич намного опередил и знаменитую философию абсурда, и философов-постмодернистов, декларирующих тотальную бессмысленность и множественность реальности. Достаточно вспомнить лишь его «работы-названия», слова в рамках, позиционируемые им как художественные полотна: «Кошелек вытащили в трамвае», «Драка на бульваре», «Полеты в Перу», «Деревня». И именно эти «лингвистические полотна» оказываются самыми сложными визуальными и семиотическими фракталами, поскольку содержат бесконечное число изображений и смыслов, «вместо писания хат уголков природы, лучше написать "Деревня", и у каждого возникает она с более подробными деталями с охватом всей деревни» [14].

Вершиной же «фрактальных изысканий» Малевича, на наш взгляд, является его великий «Черный квадрат». Но что общего у кажущейся геометрической простоты квадрата со сверхсложной фрактальностью? Да, квадрат плоский, ограниченный и монохромный, но ведь именно самое простое таит в себе самые многочисленные и сложные смыслы. Явно не обозначенные, смыслы простого множатся и ветвятся, прирастают намеками, ассоциациями, аллюзиями, реминисценциями, метафорами, аллегориями и сравнениями тем больше, чем дольше мы смотрим в «лицо» этой простоты. А самое простое - это максимально сложный семиотический фрактал. Множественность же смыслов «Черного квадрата» присутствует и в его форме (квадрат не мыслим без представлений о линии, угле, плоскости, границе, ассоциируется с кругом и другими геометрическими фигурами); и в его цвете (черный как отсутствие всякого цвета и одновременно альтернатива радужному белому, суперпозиции всех цветов); и в великом множестве иногда взаимоисключающих интерпретаций изображенного, позволяющих усмотреть в нем решительно все: «черную дыру», «абсолютный дух», 
«вселенское ничто», «дао», «абсолютную гармонию», предчувствие войны или революции, «демоническую икону» или просто икону. И Малевич не просто создает максимально перенасыщенное смыслами произведение, он целенаправленно работает над прирастанием его смыслов. Хорошо известно, что он повесил «Черный квадрат» в красный угол, по сути, сделал из него икону; тиражировал картину, выставляя ее, где только возможно, даже завещал прикрепить «черный квадрат» к гробу во время его собственных похорон.

Предельно близкий взгляд на семиотический фрактал «Черного квадрата» погружает нас в разверзнутую бездну смыслов, в хаос соединенных противоположностей (тут вспоминается Овидий с его «Метаморфозами»), в ярчайшую радугу бесцветья, в откровение и потенциальное могущество полного незнания, оглушающий шум тишины. Именно об этом впечатлении писал преданный ученик Малевича Лев Юдин в своих дневниках: «Цвет замкнутый и сдавленный, затасованный, глубокий (наслоения). Тут же вся гамма металлических звуков. Работа должна гудеть и звенеть. В итоге скованное, скорчившееся МОЛЧАНИЕ, динамический ПОКОЙ» [10, с. 167].

«Динамический покой» - силлогизм, парадокс, оксюморон, но он становится вполне понятным, определенным, наполняется точным смыслом именно в свете теории фракталов. Мы уже говорили о том, что благодаря своей топологической сложности, всякий фрактал не заполняет целиком того пространства, в котором помещается, и именно эта «степень заполнения» определяет дробность его размерности [6]. Чтобы понять это, достаточно вспомнить «фрактальную» ель с нецелой размерностью, укрытую от мороза трехмерным параллелепипедом деревянного ящика. И чем сложнее устроен фрактал, тем полнее он заполняет пространство, тем больше дробная часть его размерности. У предельно сложных фракталов дробная часть размерности стремится к единице, фрактал практически заполняет отведенное ему пространство, полностью покрывает, «заштриховывает», «заметает» его. Для иллюстрации этого факта можно представить карандаш, рисующий очень сложную, петляющую кривую, которая в пределе становится столь извилистой и запутанной, что почти полностью покрывает лист бумаги, практически не оставляя чистого места. Это именно тот случай, когда движение оказывается настолько интенсивным, что исчезает даже возможность двигаться («динамический покой»), а разноцветных штрихов, мазков становится так много, что получается плотное монохромное изображение. Это ситуация, когда многозвучие становится столь плотным, что звуки более не различаются, и возникает оглушение, «скорчившееся молчание», звенящая всеми звуками тишина. На наш взгляд, именно подобная «полная», максимальная (с почти целой размерностью) фрактальность и лежит в основании парадоксальности «Черного квадрата»: бесконечно осмысленная бессмыслица; единство всего в отсутствии; множество в единстве разделенного; дошедшее до черного смешение всех цветов; молчание тишины; перенапряженный движением покой.
Все образы, созданные Малевичем после «Черного квадрата», даже те, которые он пытался датировать более ранними сроками, угадываются безошибочно именно благодаря этим абсолютным качествам: звучащей тишине, многозвучию гасящих друг друга смыслов, бесконечной цветности черноты. Его поздние реалистические полотна, будь то «Автопортрет», «Работница» (1933) выражают то же, что выражает квадрат - семиотическую бесконечность. И тот факт, что Малевич вернулся к реализму, представляется вполне естественным и даже необходимым: в супрематизме уже не могло быть создано ничего более совершенного, чем «Черный квадрат», ставший вершиной супрематического творчества художника. И возможными остались либо восхождение на новые, совсем иные вершины, либо поворот вспять. Супрематизм же остался превосходным и доминирующим, максимумом и пределом, отражая все свои непревзойденные качества математическим смыслом своего названия.

Но фрактальные поиски Малевича на этом не закончились. Достигнув предела фрактальности на плоскости, он устремляется в пространство. Речь теперь пойдет об архитектурных скульптурах Малевича - архитектонах, в которых принципы супрематизма и фрактальности, проявились в наиболее законченном виде. В самом деле, архитектоны - это совершенные по замыслу объекты, построение которых полностью соответствуют фрактальным алгоритмам: во-первых, они обладают свойством самоподобия; во-вторых, самоподобные части архитектонов повторяются в уменьшенном масштабе, демонстрируют иерархию; в-третьих, элементы архитектонов повторяются в определенной последовательности, т. е. наличествует определенный закон фрактального роста; в-четвертых, при итерациях архитектоны приближаются к известным гладким геометрическим объектам, что соответствует их дробной и очень высокой размерности.

Архитектоны - прообразы архитектуры будущего в Супрематической Вселенной Малевича, созданые из супрематических, фрактально организованных «первоэлементов». И именно они стали новой вершиной на творческом пути художника, итогом его фрактального поиска, результатом интуитивно выстраиваемой фрактальной стратегии. Архитектоны убедительно демонстрируют, что «Черный квадрат» - это предел, но предел плоский, это не конец, а лишь начало, первоэлемент принципиально фрактального и уже объемного мира.

Итак, Малевич последовательно дробил и разрушал предметный мир, используя, по сути, фрактальные представления и фрактальные методы. Он первым в европейской культуре пришел к тому, что позднее станет известным как деконструкция. В ходе тотальной деконструкции всего существующего Малевич достиг первооснов, выделил предельные элементы, супремы, из которых может и должен созидаться любой объект, любой феномен. Супрематический мир и состоит из супрематических феноменов, созидаемых из абсолютных элементов по открытым Малевичем законам. Структура и законы этой новой Супрематической Вселенной могут быть только 
фрактальными, а сама фрактальность мыслится при этом как самая эффективная стратегия созидания (достаточно вспомнить «планиты», космические жилища из будушего!). Именно так описывал описки Малевича его ученик Лазарь Лисицкий: «Да, тропа живописной культуры сузилась, пока не превратилась в квадрат, однако на другой его стороне уже начинает плодоносить новая культура. Да, мы салютуем дерзкому человеку, который бросается в бездну с целью возродиться к жизни в другой форме. Да, живописная линия регулярно спускалась вниз... $6,5,4,3,2,1$ и 0, однако, начиная с другой крайности, мы наблюдаем рождение новой линии: 0, 1, 2, 3, 4, 5...» [26].

Супремы - это то основание, из которого и рождается «новая линия» Малевича, рождается в полном соответствии с теорией фракталов: математическая точность в построении, соподчинение и подобие, выражающие абсолютную гармонию и универсальный ритм Вселенной. Именно эта универсальность и позволила Малевичу с легкостью вернуться к живописи после создания «Черного квадрата», начать все заново, с «нуля форм». Отныне всякий раз, когда Малевич обращается к «прошлым» стилям, он словно воссоздает их заново из супрематических атомов, и от этого изображения становятся абсолютными, предельными. Ярчайшее тому подтверждение - «Девушка с гребнем в волосах» (1932-1933 гг. Холст, масло, 35,5 × 31 см, Москва, Государственная Третьяковская галерея), еще не полностью вошедшая в предметный мир, а, скорее, находящаяся «по ту сторону» супрематизма. Ее совершенство поражает настолько, что зрителю проще считать ее утопией, такой же, как и архитектоны. Иначе и быть не может: столь совершенное не может воплотиться в вещном мире, его удел - существовать в вечном мире идей, мире беспредметности, в котором помещается и вся Супрематическая Вселенная Малевича.

\section{Список источников}

1. Анисимова Е.А. Города как символические фракталы // Город и здоровье: аспекты взаимодействия. - Саратов : Саратовский источник, 2012. - С. 39-42.

2. Анисимова Е.А. Принцип совмещения визуального, семиотического и временного фракталов в «Аналитическом искусстве» П. Филонова // Искусствознание. - 2014. № 3-4. - С. 307-319.

3. Анисимова Е.А. Социальные СМИ: фрактальная структура, фрактальная динамика, фрактальные стратегии / Е.А. Анисимова. - М. : Буки-Веди, 2013. - 100 с.

4. Анисимова E.A. Текст как семиотический и лингвистический фрактал // Постмодернизм и постнеклассика: социокультурные основания. - Саратов : Саратовский источник, 2013. - C. 75-80.

5. Анисимова Е.А. Фрактальность как стратегия постнеклассических исследований процессов развития социума и культуры // Человек в условиях модернизации современного общества. - Саратов : КУБиК, 2013. - С. 84-87.
6. Анищенко В.С. Сложные колебания в простых системах : механизмы возникновения, структура и свойства динамического хаоса в радиофизических системах / В.С. Анищенко. - М. : Наука, 1990. - 312 с.

7. Афанасьева В.В. Детерминированный хаос : феноменологическо-онтологический анализ. - Саратов : Научная книга, 2002. -213 c.

8. Афанасьева В.В. Пространство: новейшая онтология / В.В. Афанасьева, К.В. Кочелаевская, А.Г. Лазерсон. Саратов : Издат. центр «Наука», 2013. - 223 с.

9. Браже Р.А. Синергетика и творчество : учеб. пособие / Р.А. Браже. - Ульяновск : УлГТУ, 2002. - 204 с.

10. Букша К. Малевич. Жизнь замечательных людей / К. Букша. - М. : Молодая гвардия, 2013. - 368 с.

11. Волошинов М.А. Математика и искусство / М.А. Волошинов. - М. : Просвещение, 2000. - 399 с.

12. Евин И.А. Когнитивные сети / И.А. Евин [и др.] // Компьютерные исследования и моделирование. - 2011. - Т. 3. № 3. - С. 231-239.

13. Литературные манифесты от символизма до наших дней. М. : XXI век - Согласие, 2000. - 608 с.

14. Малевич К. От Сезанна до Супрематизма : критический очерк / К. Малевич. - Б. м. : Изд. отд. изобразит. искусств Наркомпроса, [1920]. - 16 с.

15. Малевич К. Черный квадрат / К. Малевич. - СПб. : Азбука, 2012. - 288 c.

16. Мандельброт Б. (Не)послушные рынки: фрактальная революция в финансах / Б. Мандельброт, Р.Л. Хадсон. - М. : Вильямс, 2006. - 400 с.

17. Мандельброт Б. Фракталы и хаос. Множество Мандельброта и другие чудеса / Б. Мандельброт. - М. ; Ижевск : Регулярная и хаотическая динамика, 2009. - 392 с.

18. Мандельброт Б. Фракталы, случай и финансы / Б. Мандельброт. - М. ; Ижевск : Регулярная и хаотическая динамика, 2004. - 256 c.

19. Мандельброт Б. Фрактальная геометрия природы / Б. Мандельброт. - М. : Институт компьютерных исследований, 2002. $-656 \mathrm{c}$.

20. Николаева Е.В. Исследования фракталов в изобразительном искусстве [Электронный ресурс] // Художественная культуpa. - 2012. — № 1 (2). — URL: http://sias.ru/publications/ magazines/kultura/vypusk-2/istoriya-i-sovremennost/512. html (дата обращения: 22.11.2015).

21. Тарасенко В.В. Фрактальная семиотика : «Слепые пятна», перипетии и узнавания / В.В. Тарасенко. - М. : Либроком, 2009. - 232 c.

22. Федер Е. Фракталы / Е. Федер ; пер. с англ. - М. : Мир, 1991. - $254 \mathrm{C}$

23. Флоренский П. Мнимости в геометрии / П. Флоренский. М. : Лазурь, 1991. - 96 с.

24. Фракталы в физике : Труды 6-го международного симпозиума по фракталам в физике. - М. : Мир, 1988. - 672 с.

25. Шабетник В.Д. Фрактальная физика : Наука о мироздании / В.Д. Шабетник. - М. : Тибр, 2000. - 416 с.

26. Эль Лисицкий и его теоретическое наследие : сборник теоретической прозы Л. Лисицкого / вступ. ст., публикация, сост. Т. Горячевой. - М. : Гос. Третьяков. галерея, 1991. - 213 C.

27. Mandelbrot B.B. Fractals: Form, Chance and Dimension / B.B. Mandelbrot. - San Francisco, 1977. - 352 p. 